\title{
Two hundred years of occupational epidemiology in Norway
}

\author{
Petter Kristensen and Helge Kjuus \\ Department of Occupational Medicine and Epidemiology, National Institute of Occupational Health, Oslo, Norway \\ Correspondence: Petter Kristensen, National Institute of Occupational Health, POB 814, N-8149 Oslo, Norway \\ E-mail: pkr@stami.no Telephone: (+47) 23195373
}

\begin{abstract}
This is an open access article distributed under the Creative Commons Attribution Licence, which permits unrestricted use, distribution, and reproduction in any medium, provided the original work is properly cited.
\end{abstract}

\section{INTRODUCTION}

Occupational epidemiology in Norway can trace its roots back 200 years to the work of company physicians in the mining industry. The trajectories leading up to contemporary activity in this scientific field are both diverse and exciting. This paper aims at telling this story. We will also provide an outline of some characteristics of occupational epidemiology in contemporary Norway.

Defining the concept of occupational epidemiology is not easy. The two core elements are "work" and "health". Work and occupation are also used in general epidemiology, often as covariates and indicators of social status. By contrast, exposures related to work is the primary focus in occupational epidemiology. The separation from the study of health-related social benefits with epidemiological methods may also be subtle. Social benefits related to employment and health, e.g., sickness absence and disability pensioning, are outcomes that in some instances but not always could be defined within the frame of occupational epidemiology. Defining epidemiology is another challenge. On the one hand we have the study of case series and material without proper denominators; on the other hand there is the experiment. We have a particular problem in excluding studies with incomplete denominator data and problems in estimating disease occurrence. This is not least the case in an outline over 200 years where descriptive epidemiology dominates over analytical epidemiology during the first 150 years. Occupational epidemiology is well suited for intervention and quasiexperimental studies, e.g., in the study of physical exposures and musculoskeletal disorders. Distinguishing between epidemiological studies and experiments may therefore be difficult.

Throughout, we will use illustrative examples rather than trying to accomplish a full and systematic review. A full review would be far out of scope, but we are aware that some readers might be convinced that other examples than those chosen by us would be more relevant. To a large extent, we refer to doctoral theses.

\section{DESCRIPTIVE OCCUPATIONAL EPIDEMIO- LOGY IN THE $19^{\text {TH }}$ CENTURY}

A detailed description of conditions of work in mines and industries in Norway in the $19^{\text {th }}$ Century is provi- ded in a supplemental issue of Norsk Bedriftshelsetjeneste, edited by Haakon Natvig and Eyvind ThiisEvensen sen. (1, pp. 20-55). The outline below is mainly based on this. Norway had few industries and only 12700 were employed in industrial enterprises in 1850. Medical doctors employed in mines were probably the first who were occupied in epidemiological tasks in the occupational field. The best known worked in the silver mine in Kongsberg. Henrik Rosted was "bergmedicus" from 1792 to 1802. In 1814, after returning to his native Denmark, Rosted published a prize-awarded "medical topography" of the mining industry in Kongsberg. In addition to prose, he produced descriptive statistics (with denominator data). Annual prevalences among the miners were provided for chest disease, injuries, deafness, hernias, and other adversities. In an appendix to the national report on the health status in Norway in 1860, bergmedicus P. Klouman estimated that the mean life expectancy among the workers in the Kongsberg silver mine was 38 years whereas the mean daily illness prevalence was 1.75 percent. Occupational physicians at that time were busy in curative tasks, but Rosted and Klouman showed that primary prevention was not absent.

The national worker commission 1885 gave a more complete outline of working conditions based upon questionnaire responses from 588 enterprises.

\section{DESCRIPTIVE AND CROSS-SECTIONAL SURVEYS IN THE FIRST HALF OF THE $20^{\text {TH }}$ Century}

This period was dynamic with expanding activity in occupational hygiene and health. Carl Schiøtz started as occupational health physician at Freia Chocolade Fabrik in 1916. His aim was health promotion among the workers, in full agreement with the owner Johan Throne Holst. He was in the same period head physician at public schools in Oslo, being heavily involved in establishing regimes in health surveillance and nutritional programmes. The same concept was applied at Freia, and nutrition and a healthy life-style were as important elements as work environment. In 1932 he was appointed professor in hygiene at the University of Oslo. Other physicians as Axel Strøm and Haakon Natvig followed the same path, combining professorships in hygiene and social medicine with 
part-time positions as occupational health physicians. Other occupational health physicians got involved in research, e.g., Arne Bruusgaard and Eiler H. Schiøtz in the Oslo region and Eyvind Thiis-Evensen in Telemark (1, pp. 74-113).

The expansive growth of physicians involved in preventive work in the industry was paralleled by a similar development in the Labour Inspection. The physician Olai Lorange was leader of the Central Office of Labour Inspection, and initiated a large number of surveys and cross-sectional studies in different trades together with colleagues Arne Bruusgaard and Karl Evang (1, pp. 56-64).

The physicians in the Labour Inspection produced numerous descriptive statistics in specific trades and occupations in annual reports. Together with a growing number of occupational health physicians they staged a number of surveys (1, pp. 157-224).These were both based upon exposure characterisation (e.g., solvents, lead) and adverse health outcomes (e.g., chronic effects of organic solvents, asthma, silicosis). Eiler H. Schiøtz' survey on chronic effects of trichloroethylene exposure (2) and Karl Evang's report on asthma in the aluminium industry (3) are examples.

Most of these investigations had rather limited scientific value, but there are also examples of more comprehensive studies. Thiis-Evensen was the first, in 1941, to defend a doctoral thesis on silicosis among porcelain workers (4). Anthon Aanonsen received Carl Schiøtz' gold medal for hygiene research in 1956 for his shift work studies (5).

\section{Clinical TRIALS IN THE 1960S}

In the 1950 s and the early 1960 s a number of research projects with some common elements were carried out (1, pp. 136-143). They were mainly aimed at exploring risk factors and risk indicators of heart disease among cohorts of workers, involving a large number of enterprises. Main initiatives came from physicians at the institutes of hygiene (Haakon Natvig) and social medicine (Axel Strøm). Arne Bruusgaard with the Labour Inspection managed to mobilise a large number of occupational health physicians in these projects. Epidemiologists (Tor Bjerkedal, Knut Westlund) and several clinical researchers did also take part. Examples of the size and energy in these projects can be seen in articles by Bruusgaard (6) as well as Westlund and Nicolaysen (7).

Some of these projects were designed as RCTs. The best known was the "oil trial" and was based upon the hypothesis that dietary supplementation of linolenic acid would prevent ischemic heart disease (8). The trial involved approximately 15000 men aged 50-59 years from 280 enterprises, who were randomised into treatment and placebo groups and followed over a oneyear period $(9,10)$. It became clear that the treatment did not have the hypothesised effect. However, participants were subsequently observed as a fixed cohort after 17 years (11) and as far as 40 years (12), when nearly all participants were deceased.

These massive scientific efforts were all aimed at prevention in the general population even if the working population was targeted. Some projects were of observational nature whereas others were designed as classical RCTs. The hypotheses dealt with general lifestyle and not work environment. As such, this could definitely not be labelled occupational epidemiology. However, an interesting question is whether this boosted the further development of analytical occupational epidemiology, or if the end result was the opposite because efforts were distracted away from workplace conditions.

\section{THE ADVENT OF AETIOLOGICAL RESEARCH IN OCCUPATIONAL EPIDEMIOLOGY - THE 1970s}

It is not easy to pinpoint the start of occupational epidemiology as an analytical scientific discipline. A clinic in occupational medicine as well as an institute of occupational hygiene had been established under the Directorate of Labour Inspection already in 1947 (1, pp. 64-70). These institutions developed soon into the Institute of Occupational Health (YHI), later to be merged with institutes of work physiology and work psychology into the Work Research Institute, currently the National Institute of Occupational Health (STAMI). Their early research activities were however not so much based on epidemiological as experimental methods, toxicology, and occupational hygiene. Neither did the earlier clinical trials and research activities involving occupational health physicians develop into analytical occupational epidemiology.

A major step forward came from two other sources: the Cancer Registry of Norway and the Department of Occupational Medicine in Telemark. The topics were mainly related to occupational exposures to metal salts and asbestos and subsequent cancer.

Occupational health physicians at the Falconbridge nickel refinery in Kristiansand and local clinicians were aware of the occurrence of nasal cancer among the workers $(13,14)$. These forms of cancer were rare in the general population. Cooperation with the Cancer Registry of Norway was established, and an article with Director Einar Pedersen as first author was published already in 1973 in International Journal of Cancer (15). Senior researcher Aage Andersen at the Registry, whose background was actuarial, established and led a section for occupational cancer epidemiology during the following decades. Here, a number of projects and doctoral theses were carried out, including in-depth studies of nickel salt effects (16). Furthermore, the Cancer Registry participated in several occupational epidemiological projects initiated elsewhere.

The other source was based on research in the industrial area in Telemark, which resulted in the establishment of the Department of Occupational Medicine 


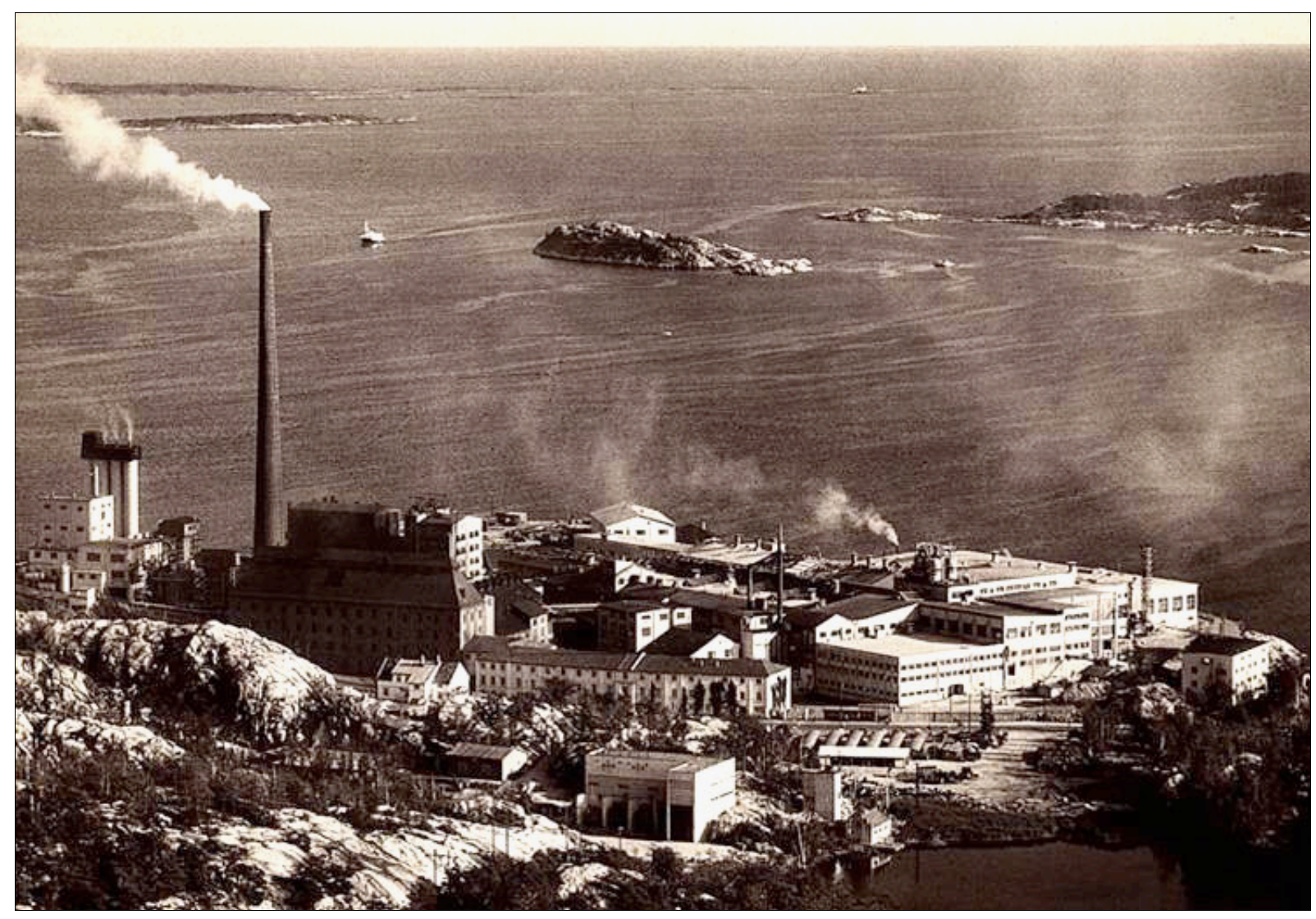

Falconbridge Nickel Refinery (Kristiansand), 1958. From company archive, unknown photographer.

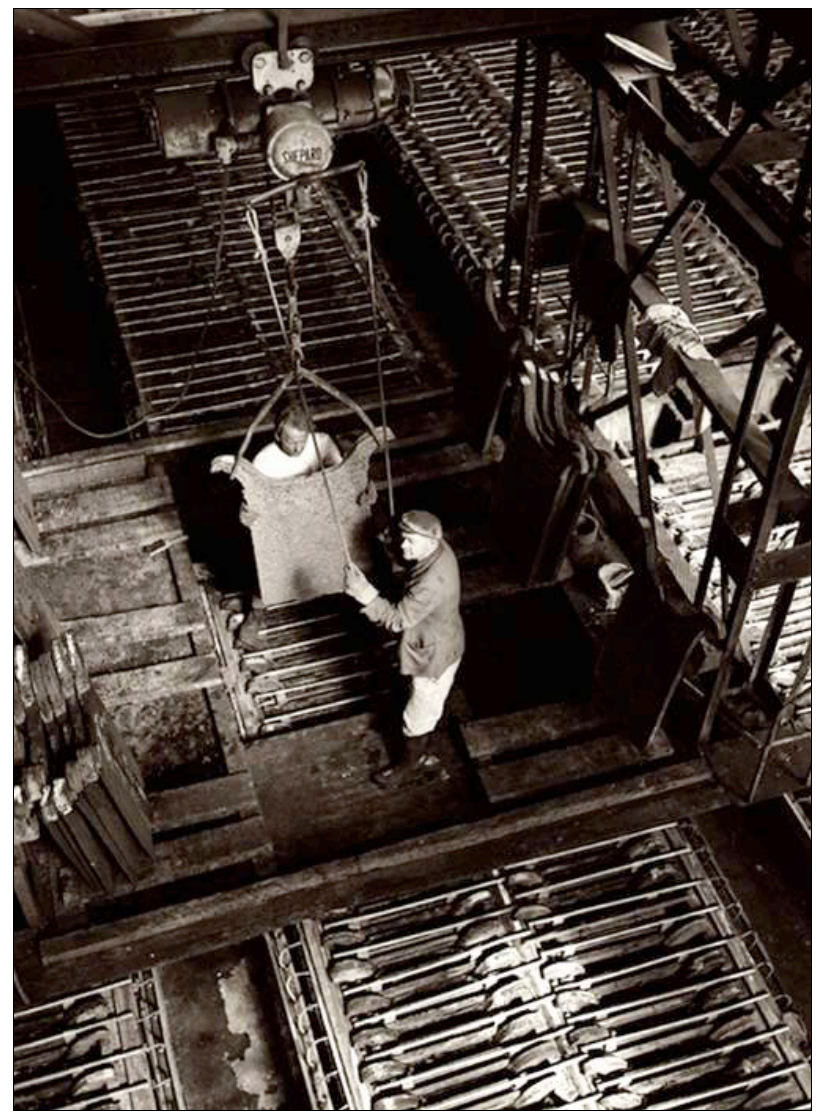

Nickel electrolysis, changing of anodes, Falconbridge Nickel Refinery (Kristiansand), 1960. Unknown photographer. in 1977. The new head of the department, Sverre Langård, finished his doctoral thesis in 1980 on occupational exposure to chromium salts and subsequent cancer development (17). This work was partly based upon an occupational cohort established by the occupational health physician Cato Broch in the late 1940s (18). Langård established co-operation with occupational toxicologists and hygienists at the National Institute of Occupational Health as well as cancer epidemiologists at the Cancer Registry $(19,20)$. Several epidemiological research projects addressing industrial chemical exposures in relation to cancer and respiratory illness followed.

\section{OCCUPATIONAL EPIDEMIOLOGY IN NORWAY DURING THE LAST DECADES}

The significance of these early research efforts can be illustrated by the appearance of a governmental report on occupational cancer already in 1975 (21). Research activity soon spread outside the Cancer Registry and the Department of Occupational Medicine in Telemark. Several elements were crucial in this development. Firstly, the establishment of departments of occupational medicine in all health regions during the late 1980s and 1990s gave opportunity for epidemiological research at these institutions. Secondly, the National Institute of Occupational Health put more emphasis on research applying epidemiological methods in the 
same period. Thirdly, the Norwegian Medical Association sponsored the establishment of Institute of Enterprise Medicine at the University of Bergen in 1990, which was led by Professor Bente Moen. This institute was established in order to promote scientific activities, including epidemiological research, within occupational health services in Norway (22). Finally, the Research Council of Norway sponsored a program aimed at strengthening epidemiology as a scientific discipline in the late $1980 \mathrm{~s}$. This program, led by professor Petter Laake at the University of Oslo, resulted in the establishment of the Norwegian Epidemiology Association NOFE in 1990. This also included a boost of occupational epidemiology.

There were of course analytical observational studies being carried out in parallel with and in addition to this. Examples of projects under the label occupational epidemiology, which resulted in doctoral theses prior to 1990, are: Victor Lindén's thesis in 1968 (23) on sickness absence, physical capacity, and ergonomic work demands; Gunnar Høvding's thesis from 1970 (24) on cement eczema; Gunnar Mowé's work on asbestos and mesothelioma in 1986 (25); and Arne Aarås' contribution regarding occupational work demands and musculoskeletal disease in 1987 (26).

Examples of Norwegian contributions in occupational epidemiology and a status overview were published in this journal in $1999(27,28)$. Since then, the research area has expanded. Chemical exposures, cancer, and pneumoconiosis are still in focus. There has been a broadening of outcomes under study: musculoskeletal disorders, chronic obstructive lung disease and asthma, neurological disorders, cardiovascular disease, mental disease, and reproductive disorders to name a few. Social benefits linked to work participation and work environment has received increased attention, and contemporary occupational epidemiology is no longer restricted to a biomedical frame but has also links to social epidemiology (29). Exposures at work include ergonomic factors and physical demands, organisation at work and work schedules, psychosocial factors, as well as physical agents. Also chemical agents of interest change, with an increasing interest in lower exposure levels as well as ultrafine and nanosize particles. The study of injury and injury prevention has for some reason not received attention in Norwegian occupational epidemiology, but there are exceptions (30,31). Occupational epidemiology in the past did concentrate on working male populations. An important part of the development has been the inclusion of studies focusing on women at work (32). There is a broadening and increased sophistication of research questions compared to the simple exposure - outcome axis: gene-environment interaction, influence of personality and personal characteristics, and the life-course concept are some examples. It should be mentioned however that what is "new" is not always so new, and there are several examples from the past that contemporary topics have a history $(3,5,23,26,33)$.

\section{IS OCCUPATIONAL EPIDEMIOLOGY A PARTICULAR FORM OF EPIDEMIOLOGY?}

Occupational epidemiology has basically evolved and developed within the same frame as other forms of epidemiology (34). A particular interest in exposure characterisation and the concept of the "healthy worker effect" is shared with occupational epidemiologists world-wide. Compared to many other countries, the opportunities for performing research on work and health are to our advantage. The climate among the main parties in working life is in favour of researchers' opportunity for access to work-places. These close ties can of course be a challenge as well, particularly with respect to conflicts of interest towards employers and employees. Access to work-places also makes intervention studies a particularly appealing design in occupational epidemiology, and there are some examples where such designs have been used $(26,35)$. Access to the work-place is often combined with linkage to other data sources. The extensive use of the Cancer Registry in combination with occupational cohorts has already been exemplified. Another much used register source is the Medical Birth Registry of Norway (36). Some of the CONOR-related data sources have also been exploited in occupational studies, mainly HUNT and HUSK in studies of populations from Nord-Trøndelag and Hordaland.

\section{WHERE DO OCCUPATIONAL EPIDEMIO- LOGISTS COME FROM AND WHERE CAN WE FIND THEM?}

In the past, occupational epidemiology in Norway was totally dominated by physicians with an interest for preventive medicine. Several combined employment in occupational health services with positions in academic institutions and regulatory agencies. This was later boosted by STAMI, the establishment of the university institute in Bergen (currently the Research Group in Occupational and Environmental Medicine), and other hospital departments in occupational medicine to follow the Telemark clinic. Also, there are activities located at institutes of community medicine at the universities as well as university colleges. Studies in occupational epidemiology have also been initiated among researchers in clinical departments, particularly (but not restricted to) lung disease (37-39). Research that can be labelled as occupational epidemiology is to-day also carried out at academic social science institutions, eg, in sociology and econometrics. Judged by the quantity of doctoral theses in recent years, the most productive units are STAMI and the research group in Bergen.

Exposure characterisation is a crucial part of occupational epidemiology. Hence, the relatively few researchers with an engineer or hygienist background who have a particular interest in epidemiology are important for method development and quality (40- 
45). Others worth special mention are the relatively few who started and led own research projects based upon experiences from their practical work in occupational health services. This was the case for the doctoral thesis of Eyvind Thiis-Evensen (4). Later, Arne Aarås $(26)$ and others $(39,46,47)$ followed. From this viewpoint, it is a pity that occupational health services to-day mainly are organised in a way that renders similar achievements in future difficult.

\section{RELATIONSHIPS TO SCIENTIFIC COMMUNITY AND FUNDERS}

During the years of expansion of analytical and aetiological research, there was rather close contact across the Nordic countries. The influence from Olli Miettinen (48) and Olav Axelson (49) was particularly strong. From the 1980s, Miettinen led method and design courses at the Finnish Institute of Occupational Health, which were attended by several Norwegian occupational epidemiologists. Somewhat later inspiration shifted over to the more frequentist concept of Ken Rothman's modern epidemiology (50). The International Commission on Occupational Health (ICOH) with its scientific committees in different disciplines including occupational epidemiology is a key forum for international scientific contact. Apart from this, several researchers in specialist disciplines as occupational respiratory disease are active in scientific fora within their speciality. It is interesting to notice that these specialised fora seem to attract more interest than scientific arenas in general epidemiology, e.g., the International Epidemiology Association. One part of the international activity is long-term programmes with the aim to train occupational epidemiologists in low- and middle-income countries to $\mathrm{PhD}$ degrees. In this work STAMI has contributed in a programme in Palestine (51), the research group in Bergen has led work in Africa (52), whilst the Department of Occupational and Environmental Medicine in Tromsø has been active in Arctic Russia (53).

The Labour Inspection Authority has had some activities in promoting occupational research in addition to the considerable contribution during the years of Olai Lorange, Arne Bruusgaard, and Karl Evang. In more recent years, support has been provided to master studies in occupational medicine and epidemiology abroad as well as to facilitate doctoral degrees for people inside own ranks (31,32). The Occupational Medicine Association has during 25 years run research courses with epidemiology as a key topic, aimed at physicians specialising in occupational medicine. The Association also award prizes to young scientists within own ranks.

Occupational epidemiologists in Norway do not seem to be particularly active in the Norwegian Epidemiology Association. During the Association's annual conferences the last five years there has only been two contributions addressing specific occupational topics. This is opposed to environmental epidemiology that usually contributes with own parallel sessions. One could speculate if occupational epidemiologists could have benefitted in quality and inspiration by establishing a closer contact with colleagues in general epidemiology.

\section{ACKNOWLEDGEMENTS}

We thank Professor Bente Moen at the University of Bergen and colleagues at several of the departments of occupational medicine for valuable input and suggestions. Occupational Health Physician Steinar R. Berge, Glencore Nikkelverk AS, and Researcher Tom K. Grimsrud, Cancer Registry of Norway, are acknowledged for providing illustrations.

\section{REFERENCES}

1. Natvig H, Thiis-Evensen E, Sen. Arbeidsmiljø og helse: yrkeshygienens og bedriftshelsetjenestens frembrudd og utvikling i Norge [in Norwegian]. Norsk Bedriftshelsetjeneste 1983; 4 (1): 1-333. ISSN 0333-0249.

2. Schiøtz EH. Forgiftninger med trikloretylen ("tri”) spesielt med henblikk på kjemiske renserier [in Norwegian]. Nord Med Tidsskr 1938; 15: 808-13.

3. Evang K. Undersøkelse hos norske aluminiumsarbeidere på forekomsten av asthma bronchiale, akutt kryolittforgiftning og "fluorose" [in Norwegian]. Nord Hyg Tidsskr 1936; 19: 117-48.

4. Thiis-Evensen E. Kiselstøvundersøkelser og silikoseforhold i en norsk porselensfabrikk [in Norwegian] [Doctoral thesis]. Oslo: Tanum, 1941: 1-254.

5. Aanonsen A. Medical problems of shift-work - summarizing the result of a six-year study of the medical problems connected with regular shift-work at three factories in Norway. Ind Med Surg 1959; 28: $422-7$.

6. Bruusgaard A. Forekomsten av hjerteinfarkt blant 60000 arbeidstakere under bedriftslægekontroll: Foreløpig meddelelse [in Norwegian]. Tidsskr Nor Laegeforen 1960; 80: 797-9.

7. Westlund K, Nicolaysen R. 10-year mortality and morbidity related to serum-cholesterol: a follow-up of 3.751 men aged 40-49. Scand J Clin Lab Invest 1972; 30 (Suppl 127): 1-24.

8. Owren PA, Hellem AJ, Ödegaard A. Linolenic acid for the prevention of trombosis and myocardial infarction. Lancet 1964; II: 975-9.

9. Natvig H. Effekten av umettede fettsyrer på hyppighten av hjerteinfarct med mer: Resultatet av bedriftslegenes "oljeforsøk" [in Norwegian]. Tidsskr Nor Lageforen 1967; 87: 1033-41. 
10. Natvig H, Borchgrevink CF, Dedichen J, Owren PA, Schiøtz EH, Westlund K. A controlled trial of the effect of linolenic acid on incidence of coronary heart disease. The Norwegian Vegetable Oil Experiment of $1965-$ 66. Scand J Clin Lab Invest 1968; 105 (Suppl): 1-20.

11. Natvig H, Bjerkedal T. Dødsrisiko, kliniske funn og laboratorieprøver hos 50-59 år gamle menn: Resultater av 17 års oppfølging av deltagerne i "Oljeforsøket” i 1964/65 [in Norwegian]. Norsk Bedriftshelsetjeneste 1986; 7: 5-16.

12. Bjerkedal T, Kristensen P, Selmer R. Levealder og dødsårsaker hos menn undersøkt ved helsekontroll i 1964. Tidsskr Nor Legeforen 2012; 132: 30-5. English version (Life expectancy and cause of death in men examined at medical check-ups in 1964) available at: http://tidsskriftet.no/article/2197795/en_GB/ (Accessed 20 May 2015).

13. Torjussen W, Solberg LK, Høgetveit AC. Histopathological changes in the nasal mucosa in active and retired nickel workers. A pilot study. Cancer 1979; 40: 568-80.

14. Torjussen W. Nasal carcinoma in nickel workers [Doctoral thesis]. Kristiansand: Kristiansand Central Hospital, 1979.

15. Pedersen E, Høgetveit AC, Andersen Aa. Cancer of respiratory organs among workers at a nickel refinery in Norway. Int J Cancer 1973; 12: 32-41.

16. Grimsrud TK. Risk of lung cancer among nickel-refinery workers: exposures and the effect of different forms of nickel [Doctoral thesis]. Oslo: Cancer Registry of Norway, Institute of Population-based Cancer Research, 2004.

17. Langård S. Carcinogenic and toxic effects of chromium: an epidemiological and experimental study [Doctoral thesis]. Oslo: Universitetsforlaget, 1980.

18. Broch C. En undersøkelse av silikoseforekomsten ved et ferrosilicium- og ferrokromsmelteverk [in Norwegian]. Nord Hyg Tidsskr 1949; 30: 1-7.

19. Langård $\mathrm{S}$, Norseth T. A cohort study of bronchial carcinomas in workers producing chromate pigments. $\mathrm{Br} J$ Ind Med 1975; 32: 62-5.

20. Langård S, Andersen Aa, Gylseth B. Incidence of cancer among ferrochromium and ferrosilicon workers. $\mathrm{Br}$ J Ind Med 1980; 37: 114-20.

21. Sosialdepartementet. Kreftfremkallende stoffer i yrkeslivet (NOU 1975:33) [in Norwegian]. Oslo: Universitetsforlaget, 1975.

22. Moen BE. Mortality of seamen on Norwegian tankers, with special reference to the nervous system [Doctoral thesis]. Bergen: University of Bergen, 1991.

23. Lindén V. Absence from work and work capacity [Doctoral thesis]. Bergen: Universitetsforlaget, 1967: 1157.

24. Høvding G. Cement eczema and chromium allergy: an epidemiological investigation [Doctoral thesis]. Bergen: University of Bergen, 1970.

25. Mowé G. Malignant mesothelioma in Norway: epidemiological, aetiological and medico-legal aspects [Doctoral thesis]. Oslo: University of Oslo, 1986.

26. Aarås A. Postural load and the development of musculo-skeletal illness [Doctoral thesis]. Oslo: Institute of Work Physiology, 1987.

27. Kristensen P, ed. Arbeidsmedisinsk epidemiologi [in Norwegian]. Norsk Epidemiologi 1999; 9 (1): 1-86.

28. Kjuus H. Norsk arbeidsmedisinsk epidemiologi: Hvor står vi? Hvor går vi? [Occupational epidemiology in Norway. Status and future challenges] [English summary]. Norsk Epidemiologi 1999; 9 (1): 5-11.

29. Kristensen P, Mehlum IS, Gravseth HM. Arbeid og yrke: Helsefremmende og helsenedbrytende faktorer [in Norwegian]. In: Mæland JG, Elstad JI, Næss Ø, Westin S (eds.): Sosial epidemiologi: Sykdommers sosiale årsaker. Oslo: Gyldendal Akademisk, 2009: 152-69. ISBN: 978-82-05-39268-7.

30. Bull N. Risk factors for occupational injuries [Doctoral thesis]. Bergen: University of Bergen, 2002.

31. Samant YS. Protecting workers: preventing work-related upper-extremity amputations [Doctoral thesis]. Trondheim: Norwegian University of Science and Technology, 2013.

32. Wergeland E. Healthy working conditions in pregnancy. An epidemiological study of work load and job control in pregnancy, in relation to maternal health and pregnancy outcome [Doctoral thesis]. Oslo: University of Oslo, 1999.

33. Kjuus H, Istad H, Langård S. Emphysema and occupational exposure to industrial pollutants. Scand J Work Environ Health 1981; 7: 290-7.

34. Kristensen P, Bakke B. Yrkesepidemiologi [in Norwegian]. In: Laake P, Hjartåker A, Thelle D, Veierød MB (eds.). Epidemiologiske og kliniske forskningsmetoder. Oslo: Gyldendal Akademisk, 2007: 499-522.

35. Skulberg K. Intervention studies of indoor air dust exposures and health in office workers [Doctoral thesis]. Oslo: University of Oslo, 2006.

36. Irgens Å, Nordby K-C, Kristensen P. Medisinsk fødselsregister i yrkesepidemiologisk forskning [In Norwegian, English summary]. Norsk Epidemiologi 2007; 17 (2): 131-40. 
37. Kongerud J. Occupational exposure and asthma. An epidemiologic study of aluminium potroom workers [Doctoral thesis]. Oslo: University of Oslo, 1991.

38. Bakke P. Obstructive airway diseases and occupational airborne exposure prevalenses and risk factors in a Norwegian community [Doctoral thesis]. Bergen: University of Bergen, 1992.

39. Søyseth V. Bronchial responsiveness in workers and children exposed to pollutants from an aluminium smelter [Doctoral thesis]. Norsk Epidemiologi 1995; 6 (suppl 1).

40. Eduard W. Assessment of mould spore exposure and relations to symptoms in wood trimmers [Doctoral thesis]. Wageningen: Landbouwuniversiteit Wageningen, 1993.

41. Rønneberg A. Mortality and cancer morbidity in workers from an aluminium smelter with prebaked carbon anodes - Part I: Exposure assessment. Occup Environ Med 1995; 52 (4): 242-9.

42. Svendsen K. Characterization of exposure to mineral oil mist and effects on the lungs and the skin of marine engineers [Doctoral thesis]. Trondheim: Norwegian University of Science and Technology, 1997.

43. Romundstad PR. Cancer risk among workers in the Norwegian aluminium industry [Doctoral thesis]. Oslo: Cancer Registry of Norway, Institute of Population-based Cancer Research, 2000.

44. Bakke B. Modelling of exposure and lung function in tunnel construction workers [Doctoral thesis]. Oslo: University of Oslo, 2004.

45. Kirkeleit J. Benzene exposure and hematological effects among offshore workers exposed to crude oil [Doctoral thesis]. Bergen: University of Bergen, 2007.

46. Skyberg K. Occupational health risks in high voltage cable workers exposed to oil mist and electromagnetic fields [Doctoral thesis]. Oslo: University of Oslo, 1992.

47. Ulvestad B. Exposure and obstructive pulmonary disease in heavy construction workers: an epidemiological study of Norwegian heavy construction workers [Doctoral thesis]. Oslo: University of Oslo, 2002.

48. Miettinen OS. Theoretical principles of occurrence research in medicine. New York: John Wiley \& Sons, 1985.

49. Axelson O. Epidemiologi för arbets- och miljömedicin [In Swedish]. Lund: Studentlitteratur, 1981.

50. Rothman K. Modern epidemiology. Boston: Little, Brown \& Co, 1986.

51. Nijem KI. Self-reported health effects and exposure to organic solvents and plastic compounds in shoe factories and workshops in Hebron City. A cross-sectional occupational health study of the workers health and working environment [Doctoral thesis]. Oslo: University of Oslo, 2002.

52. Mwaiselage J. Dust exposure and respiratory health effects in cement industry [Doctoral thesis]. Bergen: University of Bergen, 2005.

53. Shiryaeva O. Respiratory symptoms, lung function, and occupational exposure among seafood industry workers. A study among employees at Norwegian salmon factories and Russian North-West trawl fleet (Arkhangelsk) [Doctoral thesis]. Tromsø: University of Tromsø, 2012. 